\title{
THE INFLUENCE OF EVENTS DURING THE LAST FEW DAYS IN UTERO ON TISSUE DESTRUCTION AND RENAL FUNCTION IN THE FIRST TWO DAYS OF INDEPENDENT LIFE
}

\author{
BY \\ R. A. MCCANCE and E. M. WIDDOWSON \\ From the Medical Research Council Department of Experimental Medicine, University of Cambridge
}

(RECEIVED FOR PUBLICATION APRIL 26, 1954)

Since women do not begin to secrete milk freely till the third day after delivery, and no other food is available in nature for the baby, its life is maintained during the first two days after birth largely at the expense of its own tissues, and some destruction of body protein and fat is inevitable. The extent of this protein breakdown was measured by McCance and Strangeways (1954) in six normal full-term babies over the first $\mathbf{4 8}$ hours of their lives. During this time the infants were given $25-50 \mathrm{ml}$. of water but no food, and their basal metabolic rates (B.M.R.) were determined at intervals. The net amount of nitrogen $(\mathrm{N})$ appearing in the form of end-products varied from 49 to 108 and averaged $75 \mathrm{mg} . / \mathrm{kg}$. $/ 24 \mathrm{hr}$.; the B.M.R. averaged $50 \mathrm{~K}$ Cals $/ \mathrm{kg} . / 24 \mathrm{hr}$. The latter is close to the figures obtained by others. In the course of this work one baby was studied (No. 2 in the present series) who had been born after a very difficult labour and who was post-mature. His blood urea level rose to $106 \mathrm{mg}$. $/ 100 \mathrm{ml}$. and his net catabolism of protein set free $190 \mathrm{mg} . \mathrm{N} / \mathrm{kg}$. $/ 24 \mathrm{hr}$. This was considered in all probability to be unphysiological and the baby was excluded from McCance and Strangeways' normal series. It was thought at the time that events during the last few days in utero might have been responsible for the high rate of protein breakdown. The matter has now been further investigated and the results form the basis of this paper, but since the B.M.R. of the baby studied by McCance and Strangeways (1954) was perfectly normal (47.5 K Cals/kg. $/ 24 \mathrm{hr}$.), and since such determinations are extremely difficult and laborious, no further work has up to the present been done on them.

Aspects of renal function in premature infants during the first few days of life have been studied by Smith, Yudkin, Young, Minkowski and Cushman (1949), in premature and full-term infants by Hansen and Smith (1953) and in healthy full-term infants also by Thomson $(1944,1949)$ and McCance and Widdowson (1954a). The studies of McCance and Widdowson were conducted concurrently with the ones now being described, and the findings have provided standards of normality with which to compare the present ones.

\section{Subjects and Methods}

Ten full-term or post-mature baby boys who were delivered by the application of forceps have been studied. For this procedure Mother 1 was given a caudal anaesthetic; all the others a general one. The reasons why a forceps delivery was necessary varied from one baby to another as did also the condition of the infants at birth. Table 1 gives some further details of the mothers, all primiparae. of their history, labour and delivery, and of the babies they bore. These facts may be as important as the chemical findings because the two will ultimately require to be correlated more satisfactorily than is possible at present with the limited numbers available. Forceps were applied to baby 9 for maternal prophylaxis, and he and baby 10 appeared little the worse of the operation although the latter's heart rate had caused anxiety before delivery. Babies 4 and 6 were both in a bad state at birth but the latter made a rapid recovery. Babies 1, 2, 3, 5, 6 and 8 had been judged post-mature by the menstrual dates and were delivered after artificial inductions or prolonged and anxious labours. Five of them were post-mature in Clifford's $(1953,1954)$ sense of the term and all had a very hazardous entry into the world. No. 7 also appeared post-mature and it is probable that the expected date of delivery was wrong. It is impossible, however, to grade the trauma except on general clinical grounds, and there 
TABLE 1

CLINICAL NOTES ON MOTHERS AND BABIES

Mothess

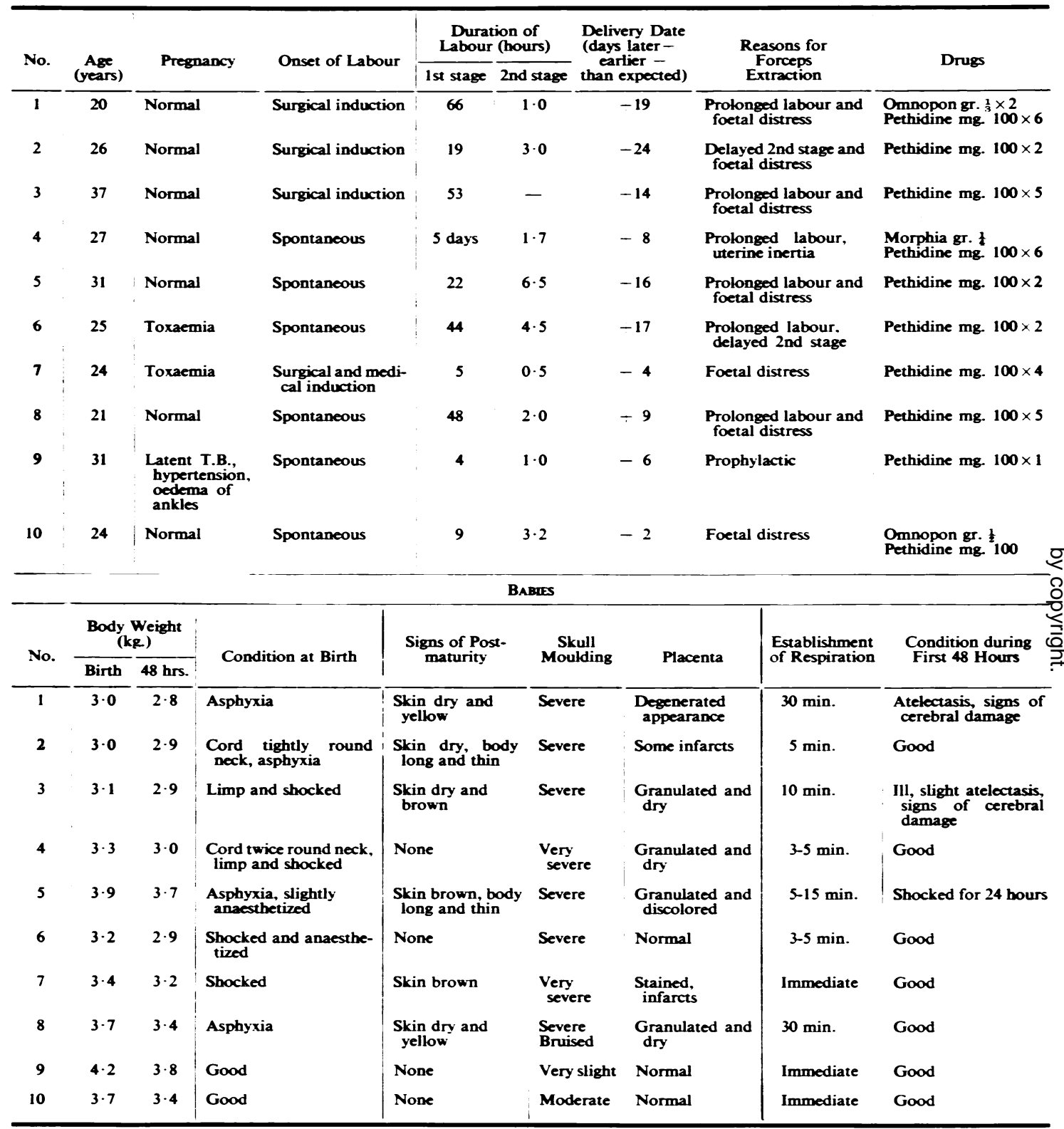

was no common yardstick by which the chemical and physical findings could be compared.

The babies were handled and nursed as described by McCance and Widdowson (1954a) and the physical and chemical methods were the same as those used by McCance and Widdowson (1953).
The figure for the net amount of nitrogen appearing in the form of end-products was calculated from the rise or fall in the amount of urea in the body fluids and the total nitrogen excreted. Clinically, all the infants did well and developed normally although some were a cause of considerable worry for a time. 


\section{Results}

Table 2 gives the volumes and the osmolar concentrations of the urines passed by the babies during the first $\mathbf{4 8}$ hours of their lives and also the average results which have been obtained in 18 normal babies delivered without forceps (McCance and Widdowson, 1954a). The volumes passed by the distressed babies were very variable but on the whole they were low and in some cases very low. It is, however, impossible to relate them confidently with any clinical grading, for baby 3 passed a volume well above the normal mean and some of the normal babies had small urine volumes. The total osmolar concentrations of the urine were much the same as those of the normal children although the concentration of urea in the blood was considerably higher

TABLE 2

VOLUMES AND TOTAL OSMOLAR CONCENTRATIONS OF URINE PASSED BY 10 BABIES DELIVERED BY FORCEPS DURING FIRST TWO DAYS OF LIFE COMPARED WITH THOSE OF 'NORMAL' BABIES SUBJECTED TO SIMILAR DEGREES OF STARVATION AND HYDROPENIA

\begin{tabular}{|c|c|c|}
\hline Baby No. & $\begin{array}{l}\text { Volume (ml. } 1 . \text { body } \\
\text { water) in } 48 \text { Hours }\end{array}$ & $\begin{array}{l}\text { Total Osmolar } \\
\text { Concentration } \\
\text { (m. osmol./1.) }\end{array}$ \\
\hline $\begin{array}{r}1 \\
2 \\
3 \\
4 \\
5 \\
6 \\
7 \\
8 \\
9 \\
10\end{array}$ & $\begin{array}{r}13 \cdot 1 \\
15 \cdot 2 \\
58 \cdot 2 \\
20 \cdot 9 \\
12 \cdot 7 \\
30 \cdot 5 \\
4 \cdot 4 \\
10 \cdot 4 \\
24 \cdot 7 \\
37 \cdot 3\end{array}$ & $\begin{array}{l}372 \\
484 \\
295 \\
459 \\
471 \\
434 \\
500 \\
408 \\
426 \\
339\end{array}$ \\
\hline Average & $22 \cdot 7$ & 419 \\
\hline $\begin{array}{c}\text { Average for 'normal' } \\
\text { babies }\end{array}$ & $27 \cdot 5$ & 420 \\
\hline Range & $8 \cdot 7-48 \cdot 7$ & $288-536$ \\
\hline
\end{tabular}

(see below). This may be a matter of age, for Kerpel-Fronius, Varga, Kun and Vönöczky (1954) always found osmolar concentrations below the normal in the urine of older infants with nitrogen retention due to dehydration.

Table 3 gives the composition of the urines, each constituent being expressed as a percentage of total osmolar concentration and again the average figures for normal babies have been added for comparison. The proportion of the osmolarity due to urea was about normal but the average proportion due to chlorides significantly less for the distressed group $(t=2 \cdot 82, p=0.01)$, and, if these babies are considered individually, babies 9 and 10 , the two most normal clinically, had perfectly normal percentages whereas babies 7 and 8 had values which were outside the normal range.

These comments about chlorides apply with greater force to potassium $(t=5.04, p=<0.001)$
TABLE 3

COMPOSITION* OF THE URINE OF 10 INFANTS DELIVERED BY FORCEPS DURING FIRST TWO DAYS OF LIFE COMPARED WITH THAT OF 'NORMAL' BABIES AND OF ADULTS SUBJECTED TO SIMILAR DEGREES OF STARVATION AND HYDROPENIA

\begin{tabular}{|c|c|c|c|c|c|}
\hline Baby No. & Urea & Chloride & Sodium & $\begin{array}{l}\text { Potas- } \\
\text { sium }\end{array}$ & $\begin{array}{l}\text { Undeter- } \\
\text { mined }\end{array}$ \\
\hline $\begin{array}{r}1 \\
2 \\
3 \\
4 \\
5 \\
6 \\
7 \\
8 \\
9 \\
10\end{array}$ & $\begin{array}{l}31 \cdot 4 \\
36 \cdot 1 \\
46 \cdot 7 \\
42 \cdot 5 \\
33 \cdot 2 \\
42 \cdot 6 \\
27 \cdot 3 \\
58 \cdot 8 \\
28 \cdot 3 \\
40 \cdot 6\end{array}$ & $\begin{array}{r}5 \cdot 3 \\
4 \cdot 5 \\
5 \cdot 1 \\
5 \cdot 5 \\
6 \cdot 3 \\
7 \cdot 4 \\
3 \cdot 3 \\
2 \cdot 2 \\
9 \cdot 7 \\
11 \cdot 3\end{array}$ & $\begin{array}{r}9 \cdot 3 \\
2 \cdot 2 \\
11 \cdot 0 \\
5 \cdot 2 \\
5 \cdot 0 \\
7 \cdot 6 \\
4 \cdot 5 \\
2 \cdot 9 \\
8 \cdot 7 \\
9 \cdot 0\end{array}$ & $\begin{array}{r}2 \cdot 2 \\
4 \cdot 7 \\
7 \cdot 0 \\
4 \cdot 4 \\
7 \cdot 8 \\
8 \cdot 3 \\
3 \cdot 8 \\
2 \cdot 2 \\
8 \cdot 3 \\
11 \cdot 5\end{array}$ & $\begin{array}{l}51 \cdot 8 \\
52 \cdot 5 \\
30 \cdot 2 \\
42 \cdot 4 \\
47 \cdot 7 \\
34 \cdot 1 \\
61 \cdot 1 \\
33 \cdot 9 \\
45 \cdot 0 \\
27 \cdot 6\end{array}$ \\
\hline Average . . & $38 \cdot 7$ & $6 \cdot 1$ & $6 \cdot 5$ & $6 \cdot 0$ & $42 \cdot 7$ \\
\hline $\begin{array}{l}\text { Average for } \\
\text { "normal" } \\
\text { babies }\end{array}$ & $37 \cdot 3$ & $10 \cdot 5$ & $7 \cdot 4$ & $11 \cdot 0$ & $33 \cdot 8$ \\
\hline Range & $22 \cdot 5-51 \cdot 7$ & $3 \cdot 7-20 \cdot 4$ & $3 \cdot 2-16 \cdot 7$ & $6 \cdot 8-14 \cdot 3$ & $11 \cdot 0-54 \cdot 4$ \\
\hline $\begin{array}{c}\text { Average for } \\
\text { adults } \quad \text {. }\end{array}$ & $47 \cdot 0$ & $7 \cdot 0$ & $9 \cdot 3$ & $4 \cdot 5$ & $32 \cdot 2$ \\
\hline
\end{tabular}

- All figures are expressed as a percentage of the total osmolar concentration.

but not to sodium, and the departure from the normal percentages for chlorides and potassium makes the percentages for the distressed babies come to lie nearer those of normal adults (McCance and Widdowson, 1954a). The undetermined percentage of the osmolar concentration had a higher average value among the distressed babies than among the normal ones $(t=2.00, p=0.05)$ and a higher value than among healthy adults. Here again, however, if the distressed babies are split up by the clinical grading, baby 10 had a low proportion of undetermined matter whereas babies 1,2 and 7 had extremely high ones.

Table 4 shows the concentration of urea in the

TABLE 4

CONCENTRATION OF UREA IN CORD SERUM OF 10 BABIES DELIVERED BY FORCEPS AND AFTER 48 HOURS OF DEHYDRATION AND HYDROPENIA

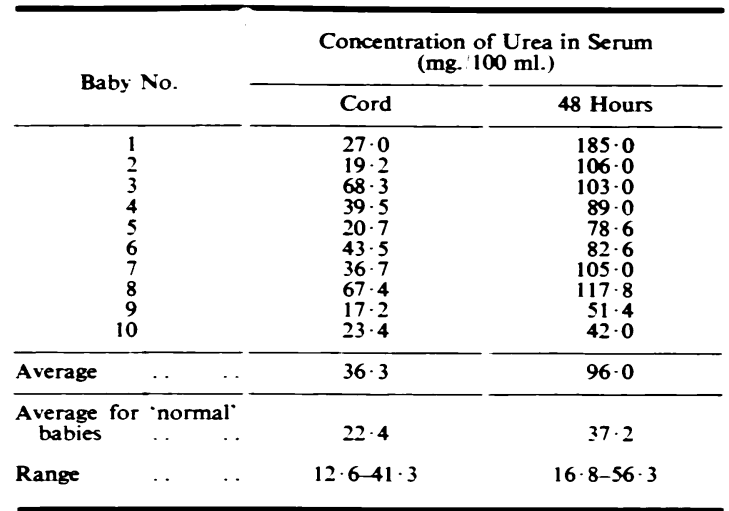


serum of each of the distressed babies at birth (cord serum) and at the end of 48 hours, and also the average value and the range for babies delivered without the aid of forceps. There is a hint, which will require confirmation, that the urea concentration in the cord blood of the distressed babies

TABLE 5

NET AMOUNT OF NITROGEN APPEARING AS ENDPRODUCTS, PROPORTION EXCRETED, AND UREA CLEARANCES OF 10 INFANTS DELIVERED BY FORCEPS DURING THE FIRST TWO DAYS OF LIFE COMPARED WITH AVERAGE VALUES FOR 'NORMAL' BABIES AND ADULTS

\begin{tabular}{|c|c|c|c|}
\hline Baby No. & $\begin{array}{c}\text { N Appearing as } \\
\text { End-products } \\
\text { (mg-kg./body } \\
\text { wt. } / 24 \mathrm{hr} .)\end{array}$ & $\begin{array}{c}\text { Percentage } \\
\text { of } \mathbf{N} \\
\text { Excreted }\end{array}$ & $\begin{array}{c}\text { Urea Clearance } \\
\text { over } 48 \text { Hours } \\
\text { (ml. } / 42 \text { l. body } \\
\text { water } / \mathrm{min} \text {.) }\end{array}$ \\
\hline $\begin{array}{r}1 \\
2 \\
3 \\
4 \\
5 \\
6 \\
7 \\
8 \\
9 \\
10\end{array}$ & $\begin{array}{l}284 \\
190 \\
146 \\
134 \\
128 \\
127 \\
124 \\
108 \\
100 \\
97\end{array}$ & $\begin{array}{r}9 \\
24 \\
66 \\
45 \\
28 \\
56 \\
11 \\
32 \\
49 \\
73\end{array}$ & $\begin{array}{r}1 \cdot 2 \\
2 \cdot 7 \\
6 \cdot 5 \\
5 \cdot 6 \\
4 \cdot 1 \\
8 \cdot 3 \\
0 \cdot 8 \\
2 \cdot 1 \\
8 \cdot 2 \\
12 \cdot 4\end{array}$ \\
\hline Average. & 144 & 39 & $5 \cdot 2$ \\
\hline $\begin{array}{l}\text { Average for } \\
\text { 'normal 'babies }\end{array}$ & 79 & 80 & $11 \cdot 9$ \\
\hline$\overline{\text { Average for adults }}$ & 174 & 96 & $37 \cdot 1$ \\
\hline
\end{tabular}

was already higher than in normal babies. There is, however, no doubt that it was much higher at the end of 48 hours. All the figures were above the normal average and all except babies 9 and 10 above the highest normal figure.

Table 5 shows the net amount of $\mathrm{N}$ appearing in the form of end-products, the proportion of this excreted and the urea clearances of the babies delivered by forceps compared as before with the normal infants and the adults. All the first named had a protein breakdown above the normal average although babies 8,9 and 10 were within the normal range. Babies 4, 5, 6 and 7 were well above it. Babies 1, 2 and 3 broke down most protein and baby 1 was outstanding in this respect. The proportion of the nitrogenous end-products which were excreted by these distressed babies averaged considerably less than it did among the normal babies but here again there were differences within the group. Babies 1, 2 and 7, the worst in so many ways, excreted less of their nitrogenous endproducts than any of the others; baby 10 excreted nearly as much as the normal average. Baby 3 was interesting in that, although his catabolism was high, his urine volume was also sufficiently high to be well above the normal average and he excreted $66^{\circ}{ }_{0}^{\circ}$ of the $\mathbf{N}$ in the protein he broke down. With urine volumes no greater than the normal, with similar osmolar concentrations and with similar percentages of this due to urea (Tables 2 and 3), it is evident that the rise in the concentration of urea in the body fluids must have meant low urea clearances and the last column in Table 4 shows that this was so. Babies 1, 2, 7 and 8 had the lowest.

Table 6 shows the total $N$ and the potassium $(\mathrm{K})$ excreted by the distressed babies in $\mathrm{mg}$. $/ \mathrm{kg}$. of body weight $/ 48 \mathrm{hr}$. It also shows the $N / K$ ratio in the urine and the ratio of the $\mathrm{N}$ appearing as endproducts to the $K$ excreted. The averages for the normal babies and the adults are also given. The amount of $\mathrm{N}$ excreted was not far from the normal. It must be pointed out that this was fortuitous, and was due to a combination of a fall in the urea clearance and a rise in the nitrogenous end-products to be excreted. Some of the babies excreted very little $K$, particularly babies 1,7 and 8 . Consequently, the $N / K$ ratios in the urine were sometimes very high and the only really normal ones were those of babies 9 and 10 . Since these distressed babies all broke down much of their body protein and tended to excrete little $\mathrm{K}$ it follows that some of them must have had very abnormal ratios for the $\mathrm{mg}$. $\mathbf{N}$ appearing as end-products per $\mathbf{K}$ excreted to the mg. Table 5 shows that this was so, and if Tables 4 and 5 are compared it will be noted that there was ano

TABLE 6

TOTAL NITROGEN AND POTASSIUM EXCRETIONS AND N/K RATIOS OF 10 BABIES DELIVERED BY FORCEPS DURING FIRST TWO DAYS OF LIFE COMPARED WITH AVERAGE VALUES FOR 'NORMAL' BABIES AND ADULTS

\begin{tabular}{|c|c|c|c|c|}
\hline Baby No. & $\begin{array}{l}\mathbf{N} \text { in Urine } \\
\text { (mg. kg. } \\
\text { body wt. } \\
24 \mathrm{hr} \text {.) }\end{array}$ & $\begin{array}{l}\text { K in Urine } \\
\text { (mg. kg. } \\
\text { body wt. } \\
24 \mathrm{hr} \text {.) }\end{array}$ & $\begin{array}{l}\text { N K Ratio } \\
\text { in Urine }\end{array}$ & $\begin{array}{l}\mathrm{N} \text { as End- } \\
\text { products } \\
\mathrm{K} \text { in Urine }\end{array}$ \\
\hline $\begin{array}{r}1 \\
\frac{2}{3} \\
4 \\
5 \\
6 \\
7 \\
8 \\
9 \\
10\end{array}$ & $\begin{array}{l}24 \cdot 9 \\
44 \cdot 5 \\
96 \cdot 0 \\
59 \cdot 8 \\
36 \cdot 0 \\
70 \cdot 5 \\
14 \cdot 0 \\
34 \cdot 9 \\
48 \cdot 5 \\
71 \cdot 0\end{array}$ & $\begin{array}{r}1.4 \\
5.2 \\
14.9 \\
5.6 \\
6.2 \\
13.9 \\
1.1 \\
1.3 \\
11.6 \\
19.6\end{array}$ & $\begin{array}{r}17 \cdot 8 \\
8 \cdot 6 \\
6 \cdot 5 \\
10 \cdot 7 \\
5 \cdot 8 \\
5 \cdot 1 \\
12 \cdot 7 \\
26 \cdot 8 \\
4 \cdot 2 \\
3 \cdot 6\end{array}$ & $\begin{array}{r}202 \cdot 0 \\
36 \cdot 5 \\
9 \cdot 8 \\
24 \cdot 0 \\
20 \cdot 7 \\
9 \cdot 2 \\
113 \cdot 0 \\
83 \cdot 0 \\
8 \cdot 6 \\
4.9\end{array}$ \\
\hline $\begin{array}{c}\text { Average for } \\
\text { normal } \\
\text { babies }\end{array}$ & $57 \cdot 9$ & $16 \cdot 6$ & $3 \cdot 5$ & $4 \cdot 8$ \\
\hline $\begin{array}{c}\text { Average for } \\
\text { adults } . .\end{array}$ & $168 \cdot 0$ & 19.9 & $8 \cdot 5$ & $8 \cdot 8$ \\
\hline
\end{tabular}

inverse relationship between the urea clearance and the urinary $N / K$ ratio, so that the higher urea clearances were associated with low ratios and vice versa.

The excretion of inorganic phosphate (P) was 
followed in the distressed babies, but the observations are so far very incomplete. Unfortunately, it was generally impossible to collect any urine which had been formed in utero, for nearly all the babies had emptied their bladders during the throes of delivery, but this was achieved in one case and sufficient specimens of urine have been obtained soon after birth to show the trend of events. The urine of baby 2 , formed in utero, contained a very high and most unusual concentration of inorganic P (74 mg./

\section{Discuscion}

The Syndrome. Events connected with a long and difficult labour seem to give rise to a syndrome in the infant which is characterized by ( $a$ ) a relatively large excretion of inorganic phosphate during and immediately after birth, $(b)$ an increased destruction of body protein during the first 48 hours of life, (c) a low urine volume, a reduced glomerular filtration rate and a poor urea clearance, $(d)$ a reduction in the contribution of $\mathrm{K}$ and $\mathrm{Cl}$ to the total
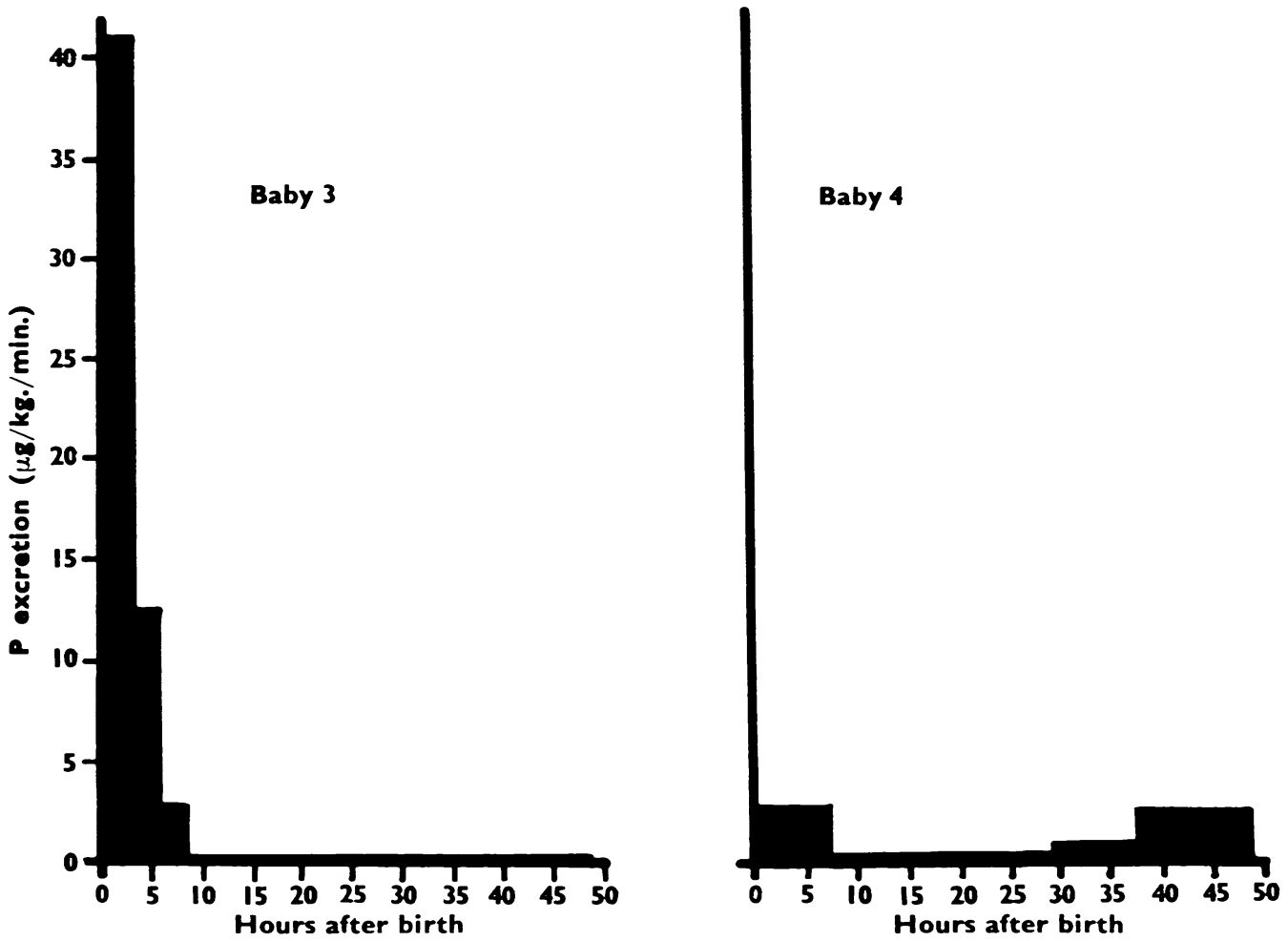

FIG. 1.-Abnormal phosphorus excretions during the first two days of life in babies 3 and 4.

$100 \mathrm{ml}$.), and Fig. 1 shows the way in which $P$ was excreted by two of the babies whose mothers had had prolonged and difficult labours. The deviation from the normal is brought out most strikingly by comparing Fig. 1 with Fig. 4 in the paper by McCance and Widdowson (1954a). Clearly the events connected with these abnormal births led to the excretion of phosphate. Resuscitation was accompanied in some infants by a fall to a perfectly normal and very low level of phosphate excretion, to be followed by a rise in the excretion rate with the normal maturation of this function. osmolarity of the urine, and certainly no increase in the former commensurate with the increase in the destruction of body protein. This reduction was compensated by an increase in the fraction designated undetermined. The syndrome is undoubtedly characterized by other deviations from the normal which have not yet been described, and, as in so many clinical syndromes, the symptoms and signs may not appear in their entirety in each and every patient.

Previous Observations. Cases of the type presented in this paper have naturally been met with 
before but it would appear that the descriptions of them have been incomplete, and the conclusions sometimes incorrect, or misleading. Snelling (1943), for example, in the course of an investigation into tetany of the newborn, described several babies aged 1-4 days who had been born only after prolonged and difficult labours and were found on admission to hospital to have high values for the non-protein nitrogen in the serum. Some of the babies also had high concentrations of inorganic $\mathbf{P}$ in their sera. A figure of $8.7 \mathrm{mg} . / 100 \mathrm{ml}$. was obtained on the first day of life and one of $10.0 \mathrm{mg}$. on the third. Snelling attributed the abnormal serum findings entirely to a disordered renal function and considered that the low serum calcium and the signs of tetany were secondary to the high serum phosphate. It is probable, however, in the light of the present findings that the most important reason for the high concentration of phosphate and of non-protein nitrogen in the serum was increased tissue destruction during and immediately after birth. Jonsson (1951) published a description of three infants who were in his opinion suffering from lower nephron nephrosis following asphyxia neonatorum. This diagnosis will not explain the urinary findings in babies 1 to 10 , for an inability to concentrate the urine and other characteristic features clearly distinguish 'lower nephron nephrosis' (Brun, 1954) from the present syndrome. Jonsson (1951), however, did not consider increased tissue destruction as one of the causes of the high non-protein nitrogen in his cases, although it probably was, and the infants were cyanosed for a long time after birth. By making certain assumptions about the concentration of urea in the blood at birth and allowances for the $\mathrm{N}$ in the food and urine, it is possible to get some estimate of the tissue destruction in these babies and the nitrogen liberated was probably over $220 \mathrm{mg}$. $/ \mathrm{kg}$./ day in two of them and about $150 \mathrm{mg}$. in the third. Some of Snelling's (1943) babies must have broken down quite as much. Campbell and Dales (1952) described a baby with sclerema neonatorum who was found to have a blood urea of $900 \mathrm{mg}$. $/ 100 \mathrm{ml}$. on the seventh day of life and histologically normal kidneys after his death on the eighth day. The authors went into the question of how to account for this high figure even with completely functionless kidneys but did not consider abnormal tissue destruction. This may have been the explanation, and a high rate of tissue destruction may be associated with sclerema, whether this is due to a lowgrade inflammatory process or to a real deviation of fatty acid metabolism (Harrison, 1926: Harrison and McNee, 1926; Hughes and Hammond, 1948). The baby was said to have had a normal and uncom- plicated delivery but it was impossible to get a good account of this.

The Cause: General Features. If we knew why the starving infant catabolized less tissue per basal calorie than an adult (McCance and Strangeways, 1954) it might be easier to discuss the cause of the increased tissue breakdown which seems to be part of the consequence of a really difficult labour. However it is to be interpreted, it would appear from the work of Stoner, Whiteley and Emery (1953) that for the first two days after birth the adrenal cortex is unresponsive to 'stress' and that variations in its hormone output should not be invoked to explain metabolic findings without due consideration. Snelling (1943) suggested that a difficult delivery, slow resuscitation, asphyxia and shock lay behind the abnormalities he observed, and Jonsson (1951) thought that asphyxia leading to "circulatory" insufficiency with more or less pronounced symptoms of shock was the cause. These suggestions may have truth in them, but they are not the whole truth. Drugs and anaesthetics, the presence-or absence - of known or unknown chemical substances may all operate, and one or other of them underlie the large variations in protein catabolism among 'normal' infants. The high rate of tissue destruction due to a deficiency of vitamin $\mathbf{B}_{12}$, which has been reported in newborn rats (Schultze, 1949: Liener and Schultze, 1950), may probably be excluded, although not as yet by experiment. In this investigation tissue destruction and renal function have been distinguished for the first time and there is reasonable evidence that both may be adversely affected by the traumatic birth but this is not invariable. A high rate of protein catabolism, moreover, has not always been found to be associated with low renal function among the normal infants. The protein catabolism of one normal baby, for example, set free $110 \mathrm{mg}$. of $\mathrm{N} / \mathrm{kg}$. of body weight/24 hr. and this infant had an excellent urine volume and urea clearance, whereas another, who catabolized less protein than any of the other infants except one, had a urea clearance of only $5 \mathrm{ml} . / 42 \mathrm{l}$./ min. Only one normal baby had a lower one.

The Cause: Detailed Considerations. It was pointed out by McCance and Widdowson (1954a) that the excretion of osmolar material, of $\mathrm{N}$ and of $\mathrm{K}$ was linked with the volume of the urine and that the major variations occurred simultaneously and in the same direction and were probably to be associated with variations in the rate of glomerular filtration. The following comments may serve to throw some light on the findings in the abnormal infants. When the glomerular filtration rate is very low and the 
breakdown of tissue protein very high, the concentration of urea and other nitrogenous end-products rises to a considerable height in the serum. A similar rise in $\mathrm{K}$ would be incompatible with life and is known, in fact, not to take place. It is suggested, therefore, that (i) the constancy of the composition of the urine in the normal infants was due to the fact that there were only small changes in the composition of the serum, and (ii) the gross rise in the concentration of urea and other nitrogenous end-products in the serum and body fluids of the distressed infants maintained the excretion of $\mathrm{N}$ at a relatively normal level in spite of their low glomerular filtration rates and urea clearances, whereas the excretion of $\mathrm{K}$, which was also coupled with the glomerular filtration rate, was low. This will explain the normal output of $\mathbf{N}$ in the distressed babies, the small output of $K$, the high $N / K$ ratios and the fact that the lower the urea clearances and glomerular filtration rates the higher the ratio was found to be. A small rise in the concentration of nitrogenous end-products in the serum is a perfectly normal finding during the first $\mathbf{4 8}$ hours of life and probably underlies the rise in the $N / K$ ratio found in the urine of the normal infants between the first and the second day of life (McCance and Widdowson, 1954a). Gamble, Ross and Tisdall (1923) showed that the $N / K$ ratio in the urine of an adult during a prolonged fast with a normal fluid intake was of the order to be expected from the breakdown of cell protoplasm and the excretion of the associated $\mathrm{N}$ end-products and salts. This may also be true of infants, for newborn animals have a lower $N / K$ ratio in their cells than adults (McCance and Widdowson, $1954 b$ ), but $N$ and $K$ are not necessarily excreted in these ratios after the forced breakdown of much cellular material. McCance and Widdowson (1937), for example, found that when acetylphenylhydrazine was used to hydrolyse the red blood corpuscles in a patient with polycythaemia there was a large rise in the concentration of urea in the plasma and much more of the $\mathrm{N}$ than of the $\mathrm{K}$ was excreted. The high $N / K$ ratio in the urine to which this gave rise offers a parallel to the findings in the abnormal babies and can be explained in a similar way. A further good example of the way in which the excretion of $\mathrm{N}$ can be maintained by a rise in the concentration of urea in the body fluids associated with a fall in the glomerular filtration rate has been provided by Yoshimura, Inoue, Yamamoto, Yamaji, Tanimura, Oohara, Takaoka, Koishi, Funaki and Hayashi (1953). The Buddhist bishop studied by them took no food or drink for eight or nine days. The non-protein nitrogen in the serum went up to six times its initial value but the glomerular filtration rate fell and with it the output of $K$. The combination of these changes increased the $N / K$ ratio of his urine from about 0.5 to about $7 \cdot 0$. The liver is quite likely to be the site within the body in which the $K$ is retained-at any rate in the first instance (Fenn, 1939; McArdle and Merton, 1952).

Until more is known about the serum values for $P$ in these abnormal infants and their exact glomerular filtration rates, it is impossible to do much to elucidate even the renal element in its excretion much less the metabolic abnormality behind it and this problem must for the moment be left unsolved.

\section{Summary}

Following a prolonged and difficult labour, fullterm and post-mature infants have been found to show some or all of the following abnormalities:

(a) An increased destruction of body protein during the first 48 hours of life; $(b)$ a reduced glomerular filtration rate, a poor urea clearance and a low urine volume; (c) a high ratio of nitrogen/ potassium in the urine; $(d)$ a large excretion of inorganic phosphate during and immediately after birth.

All the characteristic features may not be found in each case and the complete 'syndrome' may be due to multiple causes.

In this and the previous investigation we have had a great deal of cooperation and help, both in the wards and in the laboratory. We wish particularly to thank Mr. O. Lloyd, Miss J. E. Bottomley, Dr. D. M. T. Gairdner and the staff of the Maternity Hospital, Cambridge. Miss E. Colbourn, Miss G. Ives, J. W. T. Dickerson and L. A. R. Luff have also given us valuable assistance.

Brun, C. (1954). Acute Anuria: A Study Based on Renal Function Tests and Aspiration Biopsy of the Kidney. Copenhagen.

Campbell, W. A. B. and Dales, J. S. (1952). Archives of Disease in Childhood, 27, 580 .

Clifford, S. H. (1953). Amer. J. Dis. Child., 86, 319.

(1954). J. Pediat., 44, 1.

Fenn. W. O. (1939). Amer. J. Physiol.. 127, 356.

Gamble, J. L., Ross, G. S. and Tisdall. F. F. (1923). J. biol. Chem. 57. 633 .

Hansen, J. D. L. and Smith, C. A. (1953). Pediatrics, 12, 99.

Harrison, G. A. (1926). Archives of Disease in Childhood, 1, 123

and McNee, J. W. (1926). Ibid., 1. 63.

Hughes, W. E. and Hammond, M. L. (1948). J. Pediat., 32, 676

Jonsson, B. (1951). Acta paediat., Cppsala, 40, 401.

Kerpel-Fronius, Ö., Varga, F., Kun, K. and Vönöczky, J. (1954). Acta med. Acad. Sci. hung., 5, 27.

Liener. I. E. and Schultze, M. O. (1950). J. biol. Chem.. 187, 743.

McArdle, B. and Merton. P. A. (1952). J. Physiol.. Lond.. 116, 51 P.

McCance. R. A. and Strangeways, W. M. B. (1954). Brit. J. Nutr., 8. 21 .

and Widdowson, E. M. (1937). Ouart. J. Med. (N.S.), 6, 277. (1953). Proc. roy. Soc. B. 141. 488

(1954a). Archives of Disease in Childhood. 00. 000.

- - 1954b). Cold Spr. Harb. Symp.quant. Biol. To be published. Schultze, M. O. (1949). Proc. Soc. exp. Biol., N.Y., 72. 613.

Smith, C. A., Yudkin, S., Young, w.. Minkowski, A. and Cushman. M. (1949). Pediatrics, 3, 34

Snelling. C. E. (1943). J. Pediat.. 22, 559

Stoner, H. B.. Whiteley, H. J. and Emery, J. L. (1953). J. Path. Bact.. 66, 171 .

Thomson. J. (1944). Archives of Disease in Childhood, 19, 169.

Yoshigu). Ibid., 24, 180.

Yoshimura, H., Inoue, G., Yamamoto, M., Yamaji, R., Tanimura, Y.. Oohara, S., Takaoka, W.. Koishi, H., Funaki, H. and Hayashi, M. (1953). J. Biochem., Tokyo, 40, 361. 